\author{
치과위생사에 관한 일부 의료종사자의 인지도 조사 \\ 박소영 $\neq$, 원영순 \\ 벽성대학교 치위생과
}

\title{
Recognition of Health Care Workers for Dental Hygienists
}

\author{
So-Young Park $\ddagger$, Young-Soon Won \\ Department of Dental Hygiene, Byucksung University
}

\begin{abstract}
$<$ Abstract $>$
This study involved an investigation of perception of dental hygienists based on a self-reported survey of a sample of 230health care personnel working at long-term care hospitals located in Gyeonggi Province, Korea. The primary objective was to provide basic data for establishing various policies related to building up a positive image of dental hygienists as a profession.

The results were as follows. $79.1 \%$ of the respondents recognized dental hygienists as a profession. Among the titles for a dental hygienist, "teacher" was the most common with $47.4 \%$ of all. Female respondents and respondents who were able to discern between dental hygienists and nursing assistants were more likely to perceive dental hygienists positively than male respondents and ones who were not, respectively. Among social perceptions of dental hygienists was there a negative finding, that is, there was no appropriate title to address dental hygienists. This negative finding indicates that there is a vital need to enhance the perception of who are dental hygienists as a professionals level at the individual as well as institutional level.
\end{abstract}

Key Words : Dental Hygienist, Health Care Worker, Perception 


\section{I. 서론}

치과위생사는 핵심 구강보건 전문 인력으로서 치과의사와의 협력자이고 구강보건교육과 예방치 과처치 등의 중요한 업무를 수행하고 있으며[1], 의료서비스의 질을 결정하는 중요한 요인 중 하나 이다[2]. Esther Wilkins 박사(2005)는 '치과위생사 란 주요 건강을 돌보는 면허가 있는 전문인으로 구강보건교육자이고 구강질환 관리와 구강건강 촉 진을 위해 총체적인 건강을 지원하는 예방, 교육, 치료에 관한 서비스를 제공하는 임상 술식가이다' 라고 치과위생사에 대해 정의하였다[1].

우리나라의 치과위생사에 대한 교육은 1965년 3 월에 처음 실시되었고 점차적으로 치과위생사의 배출 인력이 증가하였다[3]. 2012년 현재 통계자료 에 의하면 치과위생사 면허취득자수는 52,218 명이 배출되었으나[4], 실제로 전국 요양기관에 종사하 는 치과위생사의 수는 24,138명에 불과하다[5]. 이 러한 인력의 손실을 막고 소비자가 만족하는 의료 서비스를 제공하기 위한 여러 가지 방안에 대해 생각해 보아야 할 것이다.

최근에는 치과위생사의 고유 업무와 더불어 폭 넓고 다양한 역할의 요구가 증가하고 있으며, 우수 한 인력확보를 위한 의료기관간의 경쟁이 심화되 고 있다. 이러한 요구에 부응하기 위해 치과위생사 는 직업에 대한 자질의 향상과 긍정적인 자아개념 이 확립되어야 한다[6]. 직업에 대한 정체성이 확 립되어 있지 않을 경우 직무에 대한 불만족과 이 직율을 증가시키며, 의료서비스를 제공하는 능력에 부정적 영향을 주지만[7], 직업의 만족도가 높을 경우 환자들에게 제공되는 의료서비스에 긍정적인 영향을 준다는 보고도 있다[8]. 따라서 바람직한 치과위생사의 정체성 확립은 구강보건 전문 인력 으로 업무수행에 적극적이고 긍정적인 자세로 양 질의 치과의료서비스를 환자에게 제공할 수 있도 록 하며, 이에 환자들은 치과위생사에 대한 올바르
고 바람직한 인식을 형성하게 된다[9].

치과위생사가 전문직으로 그 가치를 인정받기 위해서는 독단적인 노력으로 이루어지는 것이 아 니라 의료서비스를 받는 환자들이 그 전문직의 가 치를 인정하고 요구할 때 비로소 전문직의 존재 가치가 있는 것이다. 이에 대중이 치과위생사에 대 해 어떻게 인지하고 있느냐 하는 것은 치위생 전 문직의 발전을 위한 매우 중요한 사안이라 할 수 있다[10].

최근 치위생학계에서도 이러한 긍정적 인지의 중요성이 인식되면서 치위생학과 재학생이나 일반 인, 환자 등을 대상으로 그들이 갖고 있는 치과위 생사에 대한 인식을 측정하는 연구가 부분적으로 이루어져 왔다[10][11][12]. 그러나 그에 따른 치과 위생사의 사회적 위상에 관련한 연구 혹은 병원내 의 구성원들이 지각하는 치과위생사의 인지여부에 관한 연구는 부족한 실정이다.

이에 본 연구에서는 치과위생사들의 주요 업무 에 대한 인지정도를 파악하고 임상현장에서의 치 과위생사에 관한 인식을 조사하여 직업의 바람직 한 이미지를 구축하고 전문 직업인으로서의 치과 위생사가 발전되기 위한 기초 자료를 제공하고자 한다.

\section{II. 연구방법}

1. 연구 대상

경기도 소재 3 곳의 요양병원에 근무하는 의료종 사자 230명을 대상으로 2011년 7월 1일부터 8월 20 일까지 설문조사를 실시하였다. 병원관계자의 협 조를 얻어 소정의 교육을 받은 설문요원들이 280 부의 설문지를 배포하여 자기기입식으로 설문에 응답하도록 한 후 회수하였고, 응답이 불충분한 자 료 50 부를 제외한 230 부를 최종 자료 분석에 이용 하였다. 
2. 연구도구 및 구성

연구방법은 자기기입식 설문조사법으로 실시하 였고, 연구에 이용된 설문지는 신경선[6], 김문영 [13], 조수희[14]가 연구한 이미지에 관한 문항을 선택한 후 수정·보완하여 재구성하였다.

연구의 구성은 연령, 성별, 결혼상태, 학력, 직 업, 월수입 등 인구통계학적 변수 6문항, 치 과위생사의 인지도에 관한 24문항(업무적 인지 도 8 문항, 직업적 인지도 6 문항, 사회적 인지도 4 문항, 개인적 인지도 6문항)으로 하였다.

치과위생사에 대한 환자의 인식에 관한 사항으 로 치과위생사 인지여부, 치과위생사에 대한 호칭, 치과위생사로부터 받아 본 서비스, 치과위생사와 간호조무사의 구별여부, 간호조무사와 구분기준, 적절한 치과위생사 표시방법 등 6문항으로 구성하 였다.

치과위생사 인지도의 긍정에 관한 문항은 Likert식 5점 척도를 이용하여 매우 그렇지 않다(1 점)에서 매우 그렇다(5점)으로 산출하였으며, 부정 의 이미지에 관한 6 문항은 매우 그렇다 (1점)에서 매우 그렇지 않다(5점)으로 역환산하였으며, 점수 가 높을수록 이미지가 긍정적임을 의미한다.

\section{3. 분석 방법}

치과위생사에 대한 인지도를 측정한 24개의 설 문 문항에 대해 베리맥스기법을 통해 요인분석 (factor analysis)을 실시한 결과 치과위생사에 대한 인지도에 관한 요인 중 '치과의사의 보조적 역할만
수행한다', '힘들고 스트레스가 많은 직업이다', '성 실하고 책임감이 강하다', '기계적이고 타성적이다' 등 변수가 집중 및 판별 타당성이 없는 것으로 나 타나 합산에서 제외하였다.

변수들의 설문 신뢰도를 분석한 결과 Cronbach's $\alpha$ 계수가 업무 인지도 0.914, 직업 인 지도 0.896 , 사회적 인지도 0.871 , 개인적 인지도 0.875 이었다.

연구결과의 인구사회학적 요인과 치과위생사의 특성에 대해 빈도를 산출하고 백분율로 요약하였 다. 또한 대상자의 치과위생사 인지도를 분석하기 위하여 평균과 표준편차를 산출하는 기술통계분석 을 시행하였고, 표본의 인구사회학적 요인과 치과 위생사 특성에 따른 치과위생사 인지도의 차이를 분석하기 위하여 t-검증과 분산분석을 시행하였다.

아울러 치과위생사의 인지도에 영향을 미치는 요인을 분석하기 위하여 다중회귀분석을 시행하였 다. 회귀분석에 이용된 독립변수들은 인구통계학적 변수들이 다수 활용되었으며, 그 중 일부는 더미화 과정을 거쳤다. 성별에서는 여성을 1 , 남성을 0 , 결 혼상태에서 미혼을 1 , 기혼을 0 , 치과위생사의 인 지여부는 '있다'를 1 , '없다'를 0 , 치과위생사와 간 호조무사의 구별여부에서는 '있다'를 1 , '없다'를 0 의 점수를 부여하여 더미 변수화하였다. 모형의 설 명력은 R-Square를 통하여 파악하였으며 통계분석 은 SPSS windows ver. 12.0(SPSS Inc, USA)을 이 용하였고, 유의성검정에 이용한 유의수준은 0.05 이 었다. 


\begin{tabular}{|c|c|c|c|c|c|c|}
\hline & 내 용 & $\begin{array}{l}\text { 요인 } \\
\text { 추출값 }\end{array}$ & $\begin{array}{l}\text { 요인 } \\
\text { 적재값 }\end{array}$ & 아이겐값 & 변량 & 누적변량 \\
\hline \multirow{7}{*}{ 업무적 인지도 } & 환자를 존중하고 사랑으로 보살핀다 & .378 & .846 & \multirow{7}{*}{4.882} & \multirow{7}{*}{24.408} & \multirow{7}{*}{24.408} \\
\hline & 치료의 과정, 결과, 효과에 대해서 말해준다 & .716 & .831 & & & \\
\hline & 환자의 문제를 잘 파악하고 있다 & .713 & .814 & & & \\
\hline & 적극적으로 일한다 & .665 & .775 & & & \\
\hline & 치과의사와 환자간의 중간에서 매개역할을 한다 & .621 & .764 & & & \\
\hline & 환자 우선주의로 일을 처리한다 & .659 & .743 & & & \\
\hline & 전문직 지식과 숙련된 기술을 가지고 있다 & .668 & .640 & & & \\
\hline \multirow{5}{*}{ 직업적 인지도 } & 전문직이다 & .682 & .802 & \multirow{5}{*}{3.604} & \multirow{5}{*}{18.018} & \multirow{5}{*}{42.426} \\
\hline & 치과의사와 동료의식이 강하다 & .700 & .801 & & & \\
\hline & 사명감이 있다 & .798 & .784 & & & \\
\hline & 평생 직업으로 적합하다 & .762 & .762 & & & \\
\hline & 국민구강건강 향상에 중요한 역할을 한다 & .747 & .759 & & & \\
\hline \multirow{4}{*}{ 사회적 인지도 } & 치과 간호사라고 인식되고 있다 & .903 & .943 & \multirow{4}{*}{3.066} & \multirow{4}{*}{15.329} & \multirow{4}{*}{57.755} \\
\hline & 가치있고 보람있는 일을 한다 & .860 & .913 & & & \\
\hline & 사회적 지위가 높은 편이다 & .759 & .858 & & & \\
\hline & 호칭이 정립되어 있지 않다 & .490 & .624 & & & \\
\hline \multirow{4}{*}{ 개인적 인지도 } & 항상 바쁘게 일한다 & .878 & .910 & \multirow{4}{*}{3.016} & \multirow{4}{*}{15.080} & \multirow{4}{*}{72.835} \\
\hline & 항상 자신감 있고 당당하다 & .815 & .865 & & & \\
\hline & 친절하다 & .698 & .755 & & & \\
\hline & 청결하고 단정하다 & .694 & .733 & & & \\
\hline
\end{tabular}

\section{III. 결과}

\section{1. 연구대상자의 일반적 특성}

연구대상자의 사회 인구학적 특성은 <표 2>과 같다. 연령에서는 30 대가 $39.1 \%$ 로 가장 높게 나타 났으며, 성별에서는 여자가 $70.0 \%$ 으로 남자의 $30.0 \%$ 보다 상대적으로 많이 응답하였다. 결혼 상태
에서는 기혼이 $50.9 \%$, 미혼이 $49.1 \%$ 로 나타났고, 학력에서는 대졸이 $54.8 \%$ 로 가장 높게 나타났으며, 고졸, 대학원 이상, 중졸의 순으로 나타났다. 직업 에서는 간호사가 $26.1 \%$ 로 가장 높게 나타났으며, 요양보호사, 간호조무사, 병원행정직원, 사회복지 사, 요양사의 순으로 나타났다. 월수입에서는 $151-200$ 만원이 $30.0 \%$ 로 가장 높게 나타났으며, 101-150만원, 201-250만원, 251-300만원, 100 만원 이 하, 301만원 이상의 순으로 나타났다. 
<표 2> 연구대상자의 일반적 특성

\begin{tabular}{|c|c|c|c|}
\hline & 구분 & 빈도 & 퍼센트(\%) \\
\hline \multirow{4}{*}{ 연령 } & 20대 & 75 & 32.6 \\
\hline & 30대 & 90 & 39.1 \\
\hline & 40대 & 40 & 17.4 \\
\hline & 50대 이상 & 25 & 10.9 \\
\hline \multirow{2}{*}{ 성별 } & 남자 & 69 & 30.0 \\
\hline & 여자 & 161 & 70.0 \\
\hline \multirow{2}{*}{ 결혼상태 } & 기혼 & 117 & 50.9 \\
\hline & 미혼 & 113 & 49.1 \\
\hline \multirow{4}{*}{ 학력 } & 중졸 & 12 & 5.2 \\
\hline & 고졸 & 74 & 32.2 \\
\hline & 대졸 & 126 & 54.8 \\
\hline & 대학원 이상 & 18 & 7.8 \\
\hline \multirow{6}{*}{ 직업 } & 간호사 & 60 & 26.1 \\
\hline & 간호조무사 & 42 & 18.3 \\
\hline & 사회복지사 & 36 & 15.7 \\
\hline & 병원행정직원 & 41 & 17.8 \\
\hline & 요양사 & 6 & 2.6 \\
\hline & 요양보호사 & 45 & 19.6 \\
\hline \multirow{6}{*}{ 월수입 } & 100 만원 이하 & 20 & 8.7 \\
\hline & 101-150만원 & 68 & 29.6 \\
\hline & 151-200만원 & 69 & 30.0 \\
\hline & 201-250만원 & 36 & 15.7 \\
\hline & 251-300만원 & 26 & 11.3 \\
\hline & 301만원 이상 & 11 & 4.8 \\
\hline 합계 & & 230 & 100.0 \\
\hline
\end{tabular}

2. 치과위생사 관련 특성

연구대상자의 치과위생사 관련 특성의 결과는 <표 3>과 같다. 치과위생사 인지여부에서는 들어 본 적이 '있다'가 $79.1 \%$ 로 '없다'의 $20.9 \%$ 보다 높게 나타났다. 치과위생사 호칭에서는 '선생님'이 $47.4 \%$ 로 가장 높게 나타났으며, '언니', '치과위생 사', '간호사', '부르지 않음', '아가씨', '000씨'의 순 으로 나타났다. 치과위생사에게 받아 본 서비스에 서는 '치석제거'가 $22.7 \%$ 로 가장 높게 나타났으며, '진료보조', 'X-ray 촬영', '구강보건 교육', '치료 상 담', '접수 수납', '환자약속'의 순으로 나타났다. 치 과위생사와 간호조무사 구별여부에서는 '없다'가 $53.5 \%$, '있다'가 $46.5 \%$ 로 나타났고, 구별 기준은
'명찰착용'이 $41.1 \%$ 로 가장 높게 나타났으며, '업 무', '복장', '호칭 듣고', '대화', '기타'의 순으로 나 타났다. 적절한 치과위생사 표시방법에서는 '명찰' 이 $45.2 \%$ 로 가장 높게 나타났으며, '호칭', '복장', '면허증제시', '캡', '기타'의 순으로 나타났다.

3. 치과위생사의 인지도

연구 대상자의 치과위생사 인지도에 관한 분석 결과는 <표 $4>$ 와 같다. 전체 20 문항에 대해 $3.52 \pm 0.73$ 점으로 나타났다. 영역별로 살펴보면 업 무적 인지도는 $3.75 \pm 0.92$ 점, 직업적 인지도는 $3.51 \pm 1.06$ 점, 사회 인지도는 $3.43 \pm 1.09$ 점, 개인 인지 도는 3.39 \pm 1.07 점으로 업무적 인지도가 상대적으로 가장 높게 나타났고, 개인 인지도가 가장 낮게 나 타났다. 전체 문항별 치과위생사의 인지 여부는 '전문직 지식과 숙련된 기술을 가지고 있다'는 항 목에서 $3.84 \pm 1.11$ 점으로 가장 높게 나타났고, '친절 하다'는 항목에서 $3.19 \pm 1.28$ 점으로 가장 낮게 나타 났다. 항목별로 하부 문항을 살펴보면 업무적 인지 에서는 '전문직 지식과 숙련된 기술을 가지고 있 다'가 3.84 \pm 1.11 점으로 가장 높게 나타났고, 직업적 인지에서는 '국민구강건강 향상에 중요한 역할을 한다'가 $3.67 \pm 1.22$ 점, 사회적 인지에서는 '호칭이 정립되어 있지 않다'가 $3.52 \pm 1.31$ 점, 개인적 인지에 서는 '청결하고 단정하다'가 $3.60 \pm 1.21$ 점으로 각각 가장 높게 나타났다. 
<표 3> 치과위생사 관련 특성

\begin{tabular}{|c|c|c|c|}
\hline \multicolumn{2}{|c|}{ 구분 } & 빈도 & 퍼센트(\%) \\
\hline \multirow{2}{*}{$\begin{array}{l}\text { 치과위생사 } \\
\text { 인지여부 }\end{array}$} & 들어 본 적 있다 & 182 & 79.1 \\
\hline & 들어 본 적 없다 & 48 & 20.9 \\
\hline \multirow{7}{*}{ 치과위생사 호칭 } & 선생님 & 109 & 47.4 \\
\hline & 간호사 & 25 & 10.9 \\
\hline & 치과위생사 & 37 & 16.1 \\
\hline & 언니 & 38 & 16.5 \\
\hline & 아가씨 & 6 & 2.6 \\
\hline & 000씨 & 3 & 1.3 \\
\hline & 부르지 않음 & 12 & 5.2 \\
\hline \multicolumn{2}{|l|}{ 합계 } & 230 & 100.0 \\
\hline \multirow{12}{*}{$\begin{array}{l}\text { 치과위생사에게 } \\
\text { 받은 서비스 } \\
\text { (다중응답) }\end{array}$} & 치석제거 & 146 & 22.7 \\
\hline & 진료보조 & 101 & 15.7 \\
\hline & 식이상담 & 15 & 2.3 \\
\hline & 불소도포 & 18 & 2.8 \\
\hline & 환자약속 & 51 & 7.9 \\
\hline & 치아홈메우기 & 25 & 3.9 \\
\hline & 이 닦는 방법 & 41 & 6.4 \\
\hline & X-ray 촬영 & 70 & 10.9 \\
\hline & 치료 상담 & 54 & 8.4 \\
\hline & 구강보건 교육 & 65 & 10.1 \\
\hline & 접수 수납 & 54 & 8.4 \\
\hline & 기타 & 2 & 0.3 \\
\hline \multicolumn{2}{|l|}{ 합계 } & 642 & 100.0 \\
\hline \multirow{2}{*}{$\begin{array}{l}\text { 치과위생사와 } \\
\text { 간호조무사 } \\
\text { 구별여부 }\end{array}$} & 있다 & 107 & 46.5 \\
\hline & 없다 & 123 & 53.5 \\
\hline \multicolumn{2}{|l|}{ 합계 $\quad . . . . . . . .}$. & 230 & 100.0 \\
\hline \multirow{6}{*}{$\begin{array}{l}\text { 간호조무사와 } \\
\text { 구분 기준 }\end{array}$} & 명찰착용 & 44 & 41.1 \\
\hline & 복장 & 16 & 15.0 \\
\hline & 업무 & 22 & 20.6 \\
\hline & 대화 & 11 & 10.3 \\
\hline & 호칭 듣고 & 12 & 11.2 \\
\hline & 기타 & 2 & 1.9 \\
\hline \multicolumn{2}{|l|}{ 합계 } & 107 & 100.0 \\
\hline \multirow{6}{*}{$\begin{array}{l}\text { 적절한 } \\
\text { 치과위생사 } \\
\text { 표시방법 }\end{array}$} & 명찰 & 104 & 45.2 \\
\hline & 캡 & 3 & 1.3 \\
\hline & 복장 & 42 & 18.3 \\
\hline & 호칭 & 52 & 22.6 \\
\hline & 면허증제시 & 26 & 11.3 \\
\hline & 기타 & 3 & 1.3 \\
\hline \multicolumn{2}{|l|}{ 합계 } & 230 & 100.0 \\
\hline
\end{tabular}

<표 4> 치과위생사의 인지도

\begin{tabular}{|c|c|c|}
\hline & 내 용 & \\
\hline \multirow{7}{*}{$\begin{array}{l}\text { 업무적 } \\
\text { 인지도 }\end{array}$} & 환자를 존중하고 사랑으로 보살핀다 & $3.73 \pm 1.14$ \\
\hline & $\begin{array}{l}\text { 치료의 과정, 결과, 효과에 대해서 } \\
\text { 말해준다 }\end{array}$ & $3.72 \pm 1.15$ \\
\hline & 환자의 문제를 잘 파악하고 있다 & $3.68 \pm 1.15$ \\
\hline & 적극적으로 일한다 & $3.76 \pm 1.13$ \\
\hline & $\begin{array}{l}\text { 치과의사와 환자간의 중간에서 } \\
\text { 매개역할을 한다 }\end{array}$ & $3.81 \pm 1.13$ \\
\hline & 환자 우선주의로 일을 처리한다 & $3.77 \pm 1.15$ \\
\hline & $\begin{array}{l}\text { 전문직 지식과 숙련된 기술을 } \\
\text { 가지고 있다 }\end{array}$ & $3.84 \pm 1.11$ \\
\hline \multirow{5}{*}{$\begin{array}{l}\text { 직업적 } \\
\text { 인지도 }\end{array}$} & 전문직이다 & $3.50 \pm 1.27$ \\
\hline & 치과의사와 동료의식이 강하다 & $3.24 \pm 1.31$ \\
\hline & 사명감이 있다 & $3.59 \pm 1.25$ \\
\hline & 평생 직업으로 적합하다 & $3.57 \pm 1.29$ \\
\hline & $\begin{array}{l}\text { 국민구강건강 향상에 } \\
\text { 중요한 역할을 한다 }\end{array}$ & $3.67 \pm 1.22$ \\
\hline \multirow{4}{*}{$\begin{array}{l}\text { 사회적 } \\
\text { 인지도 }\end{array}$} & 치과 간호사라고 인식되고 있다 & $3.47 \pm 1.33$ \\
\hline & 가치있고 보람있는 일을 한다 & $3.43 \pm 1.27$ \\
\hline & 사회적 지위가 높은 편이다 & $3.32 \pm 1.23$ \\
\hline & 호칭이 정립되어 있지 않다 & $3.52 \pm 1.31$ \\
\hline \multirow{4}{*}{$\begin{array}{l}\text { 개인적 } \\
\text { 인지도 }\end{array}$} & 항상 바쁘게 일한다 & $3.39 \pm 1.29$ \\
\hline & 항상 자신감 있고 당당하다 & $3.41 \pm 1.22$ \\
\hline & 친절하다 & $3.19 \pm 1.28$ \\
\hline & 청결하고 단정하다 & $3.60 \pm 1.21$ \\
\hline \multicolumn{2}{|c|}{ 전체적인 인지도 } & $3.52 \pm 0.73$ \\
\hline
\end{tabular}


4. 인구 사회학적 특성에 따른 치과위생사의 인지도

연구대상자의 인구 사회학적 특성에 따른 치과 위생사의 인지도를 분석한 결과는 <표 $5>$ 와 같다. 연령에 따른 치과위생사의 인지도는 $\mathrm{F}=1.347$ 로서 유의수준 $5 \%$ 에서 통계적으로 유의미한 차이가 나 타나지 않았다. 하위영역을 보면 업무적 인지도에 서 $\mathrm{F}=3.261$ 로서 유의수준 $5 \%$ 에서 차이가 나타났 고, 30대에서 $3.92 \pm 0.88$ 로 가장 높게 나타났으며, 50 대 이상에서 $3.41 \pm 0.91$ 로 가장 낮게 나타났다. 성별에서는 $\mathrm{t}=-2.460$ 으로 유의수준 $5 \%$ 에서 차이가 나타났으며, 여자가 $3.80 \pm 0.90$ 으로 남자보다 더 높 게 나타났다. 하위영역을 보면 사회적 인지도에서 $t=-2.950$ 으로 유의수준 $1 \%$ 에서 차이가 나타났으며, 여자가 $3.57 \pm 1.05$ 로 더 높게 나타났다. 결혼상태에 서는 $\mathrm{t}=-1.329$ 로서 유의수준 $5 \%$ 에서 통계적으로 유의미한 차이가 나타나지 않았다. 하위영역을 보 면 업무적 인지도에서 $\mathrm{t}=-2.308$ 로서 유의수준 $5 \%$ 에서 차이가 나타났으며, 미혼이 3.89 \pm 0.97 로 더 높게 나타났다. 학력에서는 $\mathrm{F}=5.062$ 로서 유의수준 $1 \%$ 에서 차이가 나타났고, 대학원 이상에서 $4.09 \pm 0.87$ 로 가장 높게 나타났으며, 중졸에서 $3.22 \pm 0.78$ 로 가장 낮게 나타났다. 하위영역을 보면 직업적 인지도에서 $\mathrm{F}=3.043$, 개인적 인지도에서는 $\mathrm{F}=3.395$ 로 유의수준 $5 \%$ 에서 차이가 나타났고, 대 학원 이상에서 가장 높게 나타났으며, 중졸에서 가 장 낮게 나타났다. 사회적 인지도에서는 $\mathrm{F}=7.914$ 로 서 유의수준 $0.1 \%$ 에서 차이가 나타났고, 대학원 이 상에서 $3.93 \pm 1.13$ 으로 가장 높게 나타났으며, 대졸 에서 가장 낮게 나타났다. 직업에서는 $\mathrm{F}=3.241$ 로서 유의수준 $1 \%$ 에서 차이가 나타났고, 간호사가 $3.75 \pm 0.81$ 로 가장 높게 나타났으며, 병원행정직원 에서 $3.20 \pm 0.71$ 으로 가장 낮게 나타났다. 하위영역 을 보면 직업적 인지도는 $\mathrm{F}=3.080$ 으로 유의수준 $5 \%$ 에서 차이가 나타났으며, 사회복지사가 가장 높
고, 병원행정직원이 가장 낮게 나타났다. 업무적 인지도에서는 $\mathrm{F}=2.384$ 로서 유의수준 $5 \%$ 에서 차이 가 나타났으며, 사회복지사가 가장 높고, 병원행정 직원에서 가장 낮게 나타났다. 개인적 인지도에서 는 $\mathrm{F}=3.215$ 로서 유의수준 $5 \%$ 에서 차이가 나타났으 며, 간호사에서 가장 높고, 병원행정직원에서 가장 낮게 나타났다. 사회적 인지도는 $\mathrm{F}=4.530$ 으로 유의 수준 $1 \%$ 에서 차이가 나타났으며, 간호조무사에서 가장 높고, 사회복지사에서 가장 낮게 나타났다. 월수입에서는 $\mathrm{F}=1.299$ 로서 유의수준 $5 \%$ 에서 통계 적으로 유의미한 차이가 나타나지 않았다. 하위영 역을 보면 업무적 인지도에서 $\mathrm{F}=2.853$ 으로 유의수 준 $5 \%$ 에서 차이가 나타났으며, 100 만원 이하에서 가장 높고, 301만원 이상에서 가장 낮게 나타났다. 사회적 인지도에서는 $\mathrm{F}=4.968$ 로서 유의수준 $0.1 \%$ 에서 차이가 나타났고, 100 만원 이하에서 가장 높 고, 151-200만원에서 가장 낮게 나타났다.

5. 치과위생사 관련 특성에 따른 치과위생사 인지도

치과위생사 관련 특성에 따른 치과위생사 인지 도에 관한 분석한 결과는 <표 6>과 같다. 치과위 생사 인지여부에서는 $\mathrm{t}=3.753$ 으로서 유의수준 $0.1 \%$ 에서 차이가 나타났으며, '들어 본 적 있다'인 집단 이 $3.61 \pm 0.71$ 로 더 높게 나타났다. 하위영역을 보 면, 직업적 인지도는 $\mathrm{t}=2.551$, 개인적 인지도는 $\mathrm{t}=2.328$ 로서 유의수준 $5 \%$, 업무적 인지도는 $\mathrm{t}=4.662$ 로서 유의수준 $0.1 \%$ 에서 차이가 나타났으 며, '들어 본 적 있다'인 집단에서 더 높게 나타났 다. 치과위생사의 호칭에서는 $\mathrm{F}=2.060$ 으로서 유의 수준 $5 \%$ 에서 통계적으로 유의미한 차이가 나타나 지 않았다. 하위영역을 보면 직업적 인지도에서는 $\mathrm{F}=2.972$ 로서 유의수준 $1 \%$ 에서 차이가 나타났으며, 치과위생사를 부를 때 '선생님'이 가장 높고, '000 씨'가 가장 낮게 나타났다. 업무적 인지도에서는 
$\mathrm{F}=2.280$ 으로 유의수준 $5 \%$ 에서 차이가 나타났으며, '선생님'이 가장 높고, '000씨'가 가장 낮게 나타났 다. 사회적 인지도에서는 $\mathrm{F}=3.873$ 으로 유의수준 $1 \%$ 에서 차이가 나타났으며, '아가씨'가 가장 높고 '000씨'가 가장 낮게 나타났다. 치과위생사와 간호 조무사 구별여부에서는 $\mathrm{t}=5.821$ 로서 유의수준 $0.1 \%$ 에서 차이가 나타났으며, '있다'인 집단이 $3.80 \pm 0.69$ 으로 더 높게 나타났다. 하위영역을 보면 직업적 인지도는 $\mathrm{t}=5.699$, 업무적 인지도는 $\mathrm{t}=7.186$ 으로 유의수준 $0.1 \%$, 개인적 인지도는 $\mathrm{t}=3.210$ 으로 유의수준 $1 \%$ 에서 차이가 나타났으며, '있다'인 집 단에서 더 높게 나타났다. 구분 기준에서는 $\mathrm{F}=2.176$ 으로 유의수준 $5 \%$ 에서 통계적으로 유의미 한 차이가 나타나지 않았다. 하위영역을 보면 업무 적 인지도에서 $\mathrm{F}=2.388$ 로서 유의수준 $5 \%$ 에서 차이 가 나타났으며, '대화를 통해서'가 가장 높고, '호칭 을 듣고'가 가장 낮게 나타났다. 적절한 치과위생 사 표시방법에서는 $\mathrm{F}=0.709$ 로서 유의수준 $5 \%$ 에서 통계적으로 유의미한 차이가 나타나지 않았다.

\section{6. 치과위생사의 인지도에 영향을 미치는 요인}

연구대상자의 치과위생사의 인지도에 영향을 미 치는 요인에 관한 분석결과는 <표 $7>$ 과 같다. 전 체적 인지도에서는 회귀모형의 설명력이 $19.3 \%$ 로 나타났으며, $\mathrm{F}=7.601$ 로서 회귀모형이 유의미한 것 으로 나타났다. 영향력을 보면, '성별'은 유의수준 $1 \%$, '간호조무사와 구별'은 유의수준 $0.1 \%$ 에서 전 체 이미지에 정(+)의 영향을 미치는 것으로 나타났
다. 즉, 여자이고 간호조무사와 구별을 할 수 있을 수록 치과위생사의 전체 이미지도 높게 나타나고 있었다. 직업적 인지도에서는 회귀모형의 설명력이 $15.5 \%$ 로 나타났으며, $\mathrm{F}=5.840$ 으로서 회귀모형이 유 의미한 것으로 나타났다. 영향력을 보면, '성별'은 유의수준 $5 \%$, 호칭구분은 유의수준 $0.1 \%$ 에서 직업 적 인지도에 정(+)의 영향을 미치는 것으로 나타났 다. 즉, 여자이고 간호조무사와 구별을 할 수 있을 수록 치과위생사의 직업적 인지도가 높게 나타나 고 있었다. 업무적 인지도에서는 회귀모형의 설명 력이 $26.7 \%$ 로 나타났으며, $\mathrm{F}=11.560$ 으로서 회귀모 형이 유의미한 것으로 나타났다. 영향력을 보면, '치과위생사 인지여부'는 유의수준 $1 \%$, '간호조무 사와 구분'은 유의수준 $0.1 \%$ 에서 업무이미지에 정 $(+)$ 의 영향을 미치는 것으로 나타났다. 즉, 치과위 생사의 직업을 인지하고 간호조무사와 구별을 할 수 있을수록 치과위생사의 업무적 인지도도 높게 나타나고 있었다. 개인적 인지도에서는 회귀모형의 설명력이 $10.1 \%$ 로 나타났으며, $\mathrm{F}=3.553$ 으로서 회귀 모형이 유의미한 것으로 나타났다. 영향력을 보면, '성별'과 '간호조무사와 구별'에서 유의수준 $5 \%$ 에 서 개인이미지에 정(+)의 영향을 미치는 것으로 나 타났다. 즉, 여자이고 간호조무사와 구별을 할 수 있을수록 치과위생사의 개인적 인지도가 높게 나 타나고 있었다. 사회적 인지도에서는 회귀모형의 설명력이 $4.7 \%$ 로 나타났으며, $\mathrm{F}=1.570$ 으로서 회귀 모형이 유의미하지 못한 것으로 나타났다. 따라서 사회적 인지도에 영향을 미치는 요인은 없다고 볼 수가 있다. 
<표 5> 인구 사회학적 특성에 따른 치과위생사 인지도

\begin{tabular}{|c|c|c|c|c|c|c|}
\hline & \multirow{2}{*}{ 구 분 } & 업무적 인지도 & 직업적 인지도 & 사회적 인지도 & 개인적 인지도 & 전체 \\
\hline & & 평균士표준편차 & 평균 \pm 표준편차 & 평균土표준편차 & 평균士표준편차 & 평균士표준편차 \\
\hline \multirow{4}{*}{ 연령 } & 20대 & $3.79 \pm 0.94$ & $3.39 \pm 1.12$ & $3.43 \pm 1.19$ & $3.44 \pm 1.14$ & $3.51 \pm 0.77$ \\
\hline & 30대 & $3.92 \pm 0.88$ & $3.73 \pm 1.05$ & $3.34 \pm 1.10$ & $3.51 \pm 1.07$ & $3.63 \pm 0.70$ \\
\hline & 40대 & $3.51 \pm 0.89$ & $3.32 \pm 0.99$ & $3.56 \pm 0.89$ & $3.15 \pm 0.97$ & $3.38 \pm 0.63$ \\
\hline & 50대 이상 & $3.41 \pm 0.91$ & $3.39 \pm 0.95$ & $3.57 \pm 1.03$ & $3.25 \pm 0.96$ & $3.40 \pm 0.75$ \\
\hline $\mathrm{F}$ & & $3.261 *$ & 2.141 & 0.498 & 1.255 & 1.347 \\
\hline \multirow{2}{*}{ 성별 } & 남자 & $3.64 \pm 0.96$ & $3.38 \pm 1.15$ & $3.11 \pm 1.13$ & $3.24 \pm 1.08$ & $3.34 \pm 0.78$ \\
\hline & 여자 & $3.80 \pm 0.90$ & $3.57 \pm 1.02$ & $3.57 \pm 1.05$ & $3.46 \pm 1.06$ & $3.60 \pm 0.69$ \\
\hline t & & -1.155 & -1.233 & $-2.950 * *$ & -1.422 & $-2.460 *$ \\
\hline \multirow{2}{*}{ 결혼상태 } & 기혼 & $3.61 \pm 0.85$ & $3.48 \pm 0.96$ & $3.41 \pm 0.98$ & $3.33 \pm 0.96$ & $3.46 \pm 0.66$ \\
\hline & 미혼 & $3.89 \pm 0.97$ & $3.54 \pm 1.17$ & $3.46 \pm 1.19$ & $3.45 \pm 1.17$ & $3.59 \pm 0.78$ \\
\hline t & & $-2.308 *$ & -0.466 & -0.330 & -0.825 & -1.329 \\
\hline \multirow{4}{*}{ 학력 } & 중촐 & $3.47 \pm 1.10$ & $3.25 \pm 0.89$ & $3.37 \pm 1.05$ & $2.81 \pm 0.98$ & $3.22 \pm 0.78$ \\
\hline & 고졸 & $3.68 \pm 0.97$ & $3.39 \pm 1.03$ & $3.82 \pm 1.07$ & $3.32 \pm 1.14$ & $3.55 \pm 0.72$ \\
\hline & 대졸 & $3.75 \pm 0.85$ & $3.51 \pm 1.07$ & $3.14 \pm 1.02$ & $3.40 \pm 0.99$ & $3.45 \pm 0.66$ \\
\hline & 대학원 이상 & $4.25 \pm 0.92$ & $4.18 \pm 1.05$ & $3.93 \pm 1.13$ & $4.01 \pm 1.09$ & $4.09 \pm 0.87$ \\
\hline $\mathrm{F}$ & & 2.318 & $3.043 *$ & $7.914 * * *$ & $3.395 *$ & $5.062 * *$ \\
\hline \multirow{6}{*}{ 직업 } & 간호사 & $3.92 \pm 0.91$ & $3.71 \pm 1.11$ & $3.55 \pm 1.10$ & $3.84 \pm 0.92$ & $3.75 \pm 0.81$ \\
\hline & 간호조무사 & $3.76 \pm 0.90$ & $3.55 \pm 0.95$ & $3.80 \pm 0.89$ & $3.36 \pm 1.08$ & $3.62 \pm 0.66$ \\
\hline & 사회복지사 & $4.04 \pm 0.84$ & $3.88 \pm 0.98$ & $2.86 \pm 1.00$ & $3.15 \pm 1.18$ & $3.48 \pm 0.50$ \\
\hline & 병원행정직원 & $3.45 \pm 0.82$ & $3.11 \pm 1.09$ & $3.12 \pm 1.12$ & $3.14 \pm 0.99$ & $3.20 \pm 0.71$ \\
\hline & 요양사 & $3.60 \pm 0.71$ & $3.60 \pm 0.57$ & $3.41 \pm 0.80$ & $3.41 \pm 0.75$ & $3.50 \pm 0.66$ \\
\hline & 요양보호사 & $3.57 \pm 1.04$ & $3.26 \pm 1.06$ & $3.68 \pm 1.11$ & $3.25 \pm 1.11$ & $3.44 \pm 0.74$ \\
\hline$F$ & & $2.384 *$ & $3.080 *$ & $4.530 * *$ & $3.215 *$ & $3.241 * *$ \\
\hline \multirow{6}{*}{ 월수입 } & 100만원 이하 & $4.10 \pm 1.03$ & $3.41 \pm 1.08$ & $4.32 \pm 0.78$ & $3.20 \pm 1.47$ & $3.76 \pm 0.72$ \\
\hline & 101-150만원 & $3.49 \pm 0.93$ & $3.27 \pm 0.99$ & $3.54 \pm 1.03$ & $3.24 \pm 0.99$ & $3.38 \pm 0.72$ \\
\hline & 151-200만원 & $3.87 \pm 0.79$ & $3.56 \pm 1.06$ & $3.05 \pm 1.03$ & $3.44 \pm 0.92$ & $3.48 \pm 0.56$ \\
\hline & 201-250만원 & $3.96 \pm 0.92$ & $3.92 \pm 1.04$ & $3.34 \pm 1.13$ & $3.39 \pm 1.26$ & $3.65 \pm 0.75$ \\
\hline & 251-300만원 & $3.75 \pm 1.07$ & $3.59 \pm 1.28$ & $3.50 \pm 1.29$ & $3.66 \pm 1.09$ & $3.62 \pm 1.06$ \\
\hline & 301만원 이상 & $3.32 \pm 0.52$ & $3.38 \pm 0.72$ & $3.65 \pm 0.58$ & $3.77 \pm 0.72$ & $3.53 \pm 0.53$ \\
\hline$F$ & & $2.853 *$ & 1.954 & $4.968 * \star *$ & 1.022 & 1.299 \\
\hline
\end{tabular}


<표 6> 치과위생사 관련 특성에 따른 치과위생사 인지도

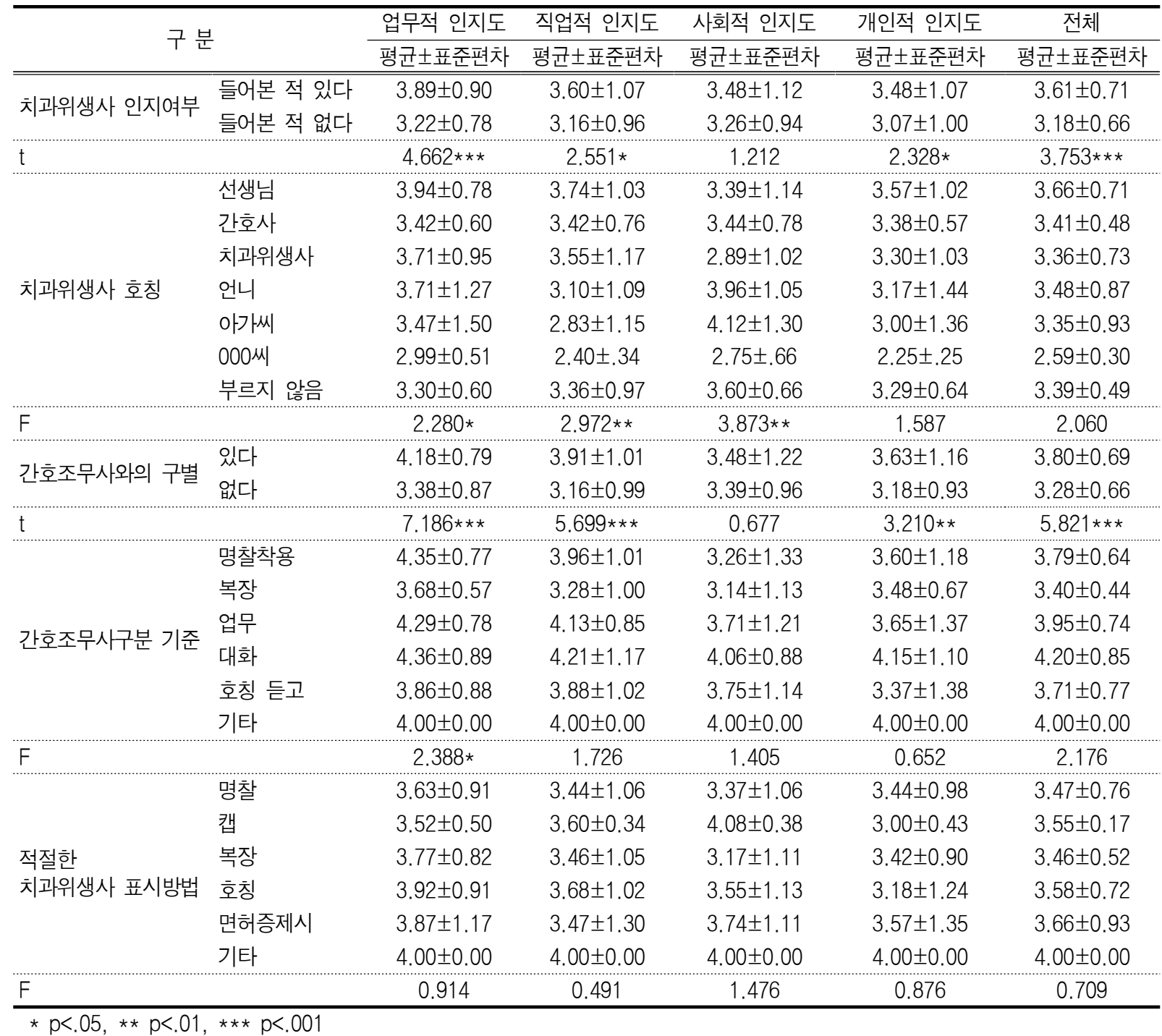


<표 7> 치과위생사의 인지도에 영향을 미치는 요인

\begin{tabular}{|c|c|c|c|c|c|c|c|}
\hline & 벼수 & 비표준혀 & 계수 & 표준화계수 & $t(n)$ & R Souare & $\mathrm{F}$ \\
\hline & 면주 & B & 표준오차 & 베타 & $\mathrm{t}(\mathrm{p})$ & R square & $r$ \\
\hline & (상수) & 3.553 & 0.551 & & 6.451 & & \\
\hline & 연령 & -0.035 & 0.062 & -0.046 & -0.555 & & \\
\hline & 성별 & 0.304 & 0.106 & 0.192 & $2.857 * *$ & & \\
\hline 저체 이지 & 결혼상태 & 0.048 & 0.116 & 0.033 & 0.413 & & \\
\hline 선제 인시노 & 학력 & 0.114 & 0.088 & 0.110 & 1.296 & 0.193 & $7.601 * \star \star \star$ \\
\hline & 월수입 & -0.001 & 0.048 & -0.002 & -0.020 & & \\
\hline & 치과 위생사 인지여부 & 0.205 & 0.116 & 0.115 & 1.766 & & \\
\hline & 간호조무사와 구별여부 & 0.463 & 0.096 & 0.318 & $4.850 * * *$ & & \\
\hline & (상수) & 3.361 & 0.827 & & 4.062 & & \\
\hline & 연령 & -0.004 & 0.094 & -0.003 & -0.039 & & \\
\hline & 성별 & 0.324 & 0.160 & 0.139 & $2.028 *$ & & \\
\hline 직업적 & 결혼상태 & 0.007 & 0.175 & 0.003 & 0.039 & 155 & 5010 \\
\hline 인지도 & 학력 & 0.199 & 0.133 & 0.130 & 1.501 & 0.155 & 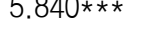 \\
\hline & 월수입 & 0.018 & 0.072 & 0.022 & 0.253 & & \\
\hline & 치과 위생사 인지여부 & 0.103 & 0.174 & 0.039 & 0.591 & & \\
\hline & 간호조무사와 구별여부 & 0.690 & 0.143 & 0.323 & $4.806 * * *$ & & \\
\hline & (상수) & 5.091 & 0.668 & & 7.626 & & \\
\hline & 연령 & -0.127 & 0.076 & -0.133 & -1.677 & & \\
\hline & 성별 & 0.105 & 0.129 & 0.052 & 0.816 & & \\
\hline 업무적 & 결혼상태 & 0.031 & 0.141 & 0.017 & 0.217 & & \\
\hline 인지도 & 학력 & 0.171 & 0.107 & 0.130 & 1.602 & 0.267 & $11.560 * \star \star$ \\
\hline & 월수입 & -0.105 & 0.058 & -0.147 & -1.793 & & \\
\hline & 치과 위생사 인지여부 & 0.403 & 0.141 & 0.177 & $2.864 * *$ & & \\
\hline & 간호조무사와 구별여부 & 0.727 & 0.116 & 0.393 & $6.280 * * *$ & & \\
\hline & (상수) & 2.723 & 0.857 & & 3.178 & & \\
\hline & 연령 & -0.072 & 0.097 & -0.065 & -0.738 & & \\
\hline & 성별 & 0.391 & 0.165 & 0.168 & $2.363 *$ & & \\
\hline 개인적 & 결혼상태 & 0.042 & 0.181 & 0.020 & 0.230 & & \\
\hline 인지도 & 학력 & 0.154 & 0.137 & 0.101 & 1.124 & 0.101 & $3.553 * *$ \\
\hline & 월수입 & 0.096 & 0.075 & 0.117 & 1.281 & & \\
\hline & 치과 위생사 인지여부 & 0.207 & 0.180 & 0.079 & 1.146 & & \\
\hline & 간호조무사와 구별여부 & 0.334 & 0.149 & 0.156 & $2.246 *$ & & \\
\hline & (상수) & 3.037 & 0.901 & & 3.371 & & \\
\hline & 연령 & 0.064 & 0.102 & 0.056 & 0.622 & & \\
\hline & 성별 & 0.395 & 0.174 & 0.166 & $2.271 *$ & & \\
\hline 사회적 & 결혼상태 & 0.113 & 0.190 & 0.052 & 0.594 & & \\
\hline 인지도 & 학력 & -0.067 & 0.144 & -0.043 & -0.465 & 0.047 & 1.570 \\
\hline & 월수입 & -0.013 & 0.079 & -0.016 & -0.171 & & \\
\hline & 치과 위생사 인지여부 & 0.107 & 0.190 & 0.040 & 0.562 & & \\
\hline & 간호조무사와 구별여부 & 0.102 & 0.156 & 0.047 & 0.656 & & \\
\hline
\end{tabular}

주1) 성별(남성), 결혼상태(기혼), 치과위생사 인지여부(없다), 간호조무사와 구별여부 (없다)가 각각 기준집단임

주2) * $p<.05, * * p<.01, * * * p<.001$ 


\section{IV. 고찰}

우리나라에 치과위생사가 정착한지도 벌써 50여 년이 되어간다. 반백년의 세월 속에서 학문적인 발 전과 임상에서 치과위생사의 활약은 눈부시게 성 장하였다[15]. 2011년 한국고용정보원의 조사에 따 르면 치과위생사의 직업 만족도는 치과의사나 간 호사보다 높다는 보고와 같이 치과위생사의 긍정 적인 직업 인식이 나날이 높아지고 있다[16]. 그러 나 다른 일면에 질 높은 의료서비스를 요구하는 사회적 상황과 국민의 인식변화가 치과의사와 협 력하여 의료서비스를 제공하는 치과위생사의 다양 한 역할을 기대하므로 인해[17] 이들은 직무의 스 트레스를 받게 되며 주요 원인을 극복하지 못하고 정신적·육체적인 탈진상태의 자아의식을 갖는 경 우도 증가하고 있다고 한다[18].

이러한 직업의 부정적 자아개념을 개선시키기 위한 방안으로 사회적으로 치과위생사 직업의 인 지도가 긍정적으로 전환이 된다면 임상에서 활동 하는 이들의 업무 만족도가 높아지고 환자들에 게 제공되는 의료서비스의 질도 향상될 것이다. 향 상된 의료서비스를 제공하기 위해서는 치과위생사 의 직업에 대한 정체성 확립과 환자가 원하는 치 과위생사의 인식과 선호양상을 파악하는 것이 매 우 중요할 것이다.

Mendez \& Louis는 간호사에 대한 대중적 인식 은 집단간의 격차를 야기하고 계속 부정적 인식으 로 비추어질 경우에는 그들의 삶과 포부에 영향을 미치게 될 것이며, 나아가 업무수행의 효율성을 감 소시키게 된다며 인식이 주는 영향의 중요성을 강 조하였다[19].

이에 치과위생사의 역할에 대한 기대가 높아지 는 현 시점에서 의료계 종사자들의 치과위생사에 대한 선호양상을 파악하여 치과위생사가 전문 직 업인으로서의 발전을 도모하기 위한 자료로 활용 하고자 본 조사를 수행하였고 그 결과에 대해 논
의하고자 한다.

연구 대상자의 치과위생사에 대한 인지여부에 대해 살펴보면 치과위생사라는 직업을 $79.1 \%$ 가 알 고 있다고 응답하였다. 이는 치과 방문 환자를 대 상으로 조사한 유미선[9]의 연구에서 $76.1 \%$, 조수 희[14]의 연구에서 $47 \%$ 보다 높게 나타났으며, 대학 생을 대상으로 조사한 이보영 등[11]에서 $78.5 \%$ 로 응답한 조사보다도 높게 나타났다. 이는 응답자가 현 의료계에 종사하는 사람들이므로 일반인보다는 좀 더 치과위생사라는 직업군에 대한 정보를 접할 기회가 많기 때문이라 생각된다.

치과위생사에게 받아 본 서비스에는 치석제거를 가장 많이 받았다고 응답하였으며 이는 유미선[9], 최은미 등[12]의 연구에서 치과의사의 보조 업무가 가장 높게 나타난 결과와는 다소 상이한 결과로 치과위생사의 고유의 업무 중 예방업무에 대한 인 식이 좀 더 개선되었음을 알 수 있으나, 진료 보조 업무가 두 번째로 높은 결과를 보여 점진적으로 치과위생사의 업무에 대한 인식변화를 가져오기 위해서는 진료보조업무를 대신 할 대체 인력의 확 보와 치과의사를 비롯한 치과에 종사하는 사람들 의 전반적인 인식 개선이 필요하다.

치과위생사와 간호조무사를 구별하는 방법과 적 절한 치과위생사 표시방법에서는 명찰을 보고 구 별한다는 응답이 각각 $41.1 \%, 45.2 \%$ 로 가장 높게 나타났는데, 이는 치과위생사의 전문 직업인 이미 지로 상징 되어지는 요인이 명찰이라고 응답한 유 미선[9], 최은미 등[12], 조수희[14]의 연구결과와 일치하였다. 이에 임상에서의 적극적인 명찰 패용 을 통해 치과위생사의 직업을 알리고 간호조무사 와는 차별화된 업무 기술을 통해 전문 의료기사임 을 홍보함으로써 위상을 높여 나아가야 할 것이다. 또한 2012년 대한치과위생사협회에서는 치과위생 사의 직업적 존엄성을 상징하는 '치과위생사 문장 패용 캠페인’을 추진하여 공동체 의식을 통한 결속 력을 강화하고 대외적인 치과위생사의 이미지 정 
립에 도움을 주고자 활동을 하고 있다[20].

치과위생사의 긍정적 인식으로는 '전문직 지식 과 숙련된 기술을 가지고 있다'가 높게 나타났고, 이는 대학생들을 대상으로 조사한 이보영 등[11]의 연구결과와 일치하였다. 이의 결과는 치과위생사들 에게 긍정적인 자아개념을 확립시키는 데 발판이 되어 그들을 전문직으로써 발전할 수 있도록 할 것이다. 치과위생사는 '청결하고 단정하다'가 가장 높게 나타났고, 이는 이보영 등[11], 황미영 등[21] 의 연구결과와 일치하였다. 이에 복장과 용모가 치 과위생사의 이미지 형성에 중요한 요소로 인식되 고 있다고 할 수 있다. 치과위생사의 전문 직업인 이미지 선호 조사에서 밝은 표정, 단정한 외모, 환 자의 질문에 대한 친절한 설명이 환자들의 만족에 영향을 미친다는 연구 결과[22]를 감안할 때 치과 위생사의 정갈한 이미지는 환자에게 긍정적 효과 를 주어 좀 더 효율적인 진료의 결과와 직업의 이 미지를 개선시킬 수 있을 것이다.

치과위생사의 부정적인 인식으로는 직업적 인지 도에서 치과위생사는 '치과의사와 동료의식이 약하 다라고 응답하였는데, 의료기관내에서 팀으로 구 성되어 있는 치과의사와 치과위생사가 가족 같은 구성원으로 서로 신뢰하며 병원을 가정 같이 따뜻 한 분위기로 조성하여야 환자 역시 편안한 의료 서비스를 누릴 수 있기에 좀 더 협력적이고 좋은 팀웍을 이루고자 노력해야 한다고 사료된다[23]. 또한 치과위생사를 부를 때 사용하는 호칭은 '선생 님'이 $47.4 \%$ 로 가장 높았고, 그 다음으로는 '언니', '치과위생사', '간호사'순이었다. 이는 대학생들을 대상으로 조사한 이보영 등[11]의 연구결과와 유사 하였고, 치과위생사라는 직업인의 호칭이 사회적으 로 아직 미정립되어 있고, 직업의 홍보 또한 부족 한 결과라 사료된다. 이에 개인적-사회적으로 적극 적인 홍보 활동을 통하여 치과위생사의 명칭과 고 유 업무, 임상에서 치과위생사의 역할이 국민들에 게 올바르게 인식되어져야 할 것이다.
본 연구의 제한점으로는 연구에 이용된 대상자 가 일부 지역 요양병원에 근무하는 의료종사자만 을 대상으로 하여 표본수가 적어 모집단을 대표하 기에는 다소 부족한 점이 있으나, 이와 같이 일부 의 의료종사자의 치과위생사에 대한 인지여부를 조사하여 바람직한 치과위생사 직업의 이미지를 재정립하는데 필요한 기초자료를 제시하는 데는 의의가 있다고 하겠다.

향후에는 본 연구의 자료와 분석방법의 제한점 을 완화시킨 실증적 연구가 더 나와야 할 것이며, 치과위생사가 전문 직업군임을 인식시킬 수 있는 임상에서의 개인적 이미지 개선 노력과 정부 차원 의 적극적이고 다양한 정보 매체활용 및 홍보 프 로그램을 지속적으로 개발하고 정책적 과제 등을 보완하는 것이 필요하리라고 검토 되었다.

\section{$\mathrm{V}$. 결론}

본 연구는 경기도 소재 요양병원에 근무하는 의 료종사자를 편의표본추출하여 230 명을 대상으로 치과위생사에 관한 인지도를 조사하여 분석한 결 과 다음과 같은 결론을 도출하였다.

1) 의료종사자들은 치과위생사의 직업을 인지하 고 있다가 $79.1 \%$ 으로 높게 나타났고, 치과위생사를 부르는 호칭은 '선생님'이 $47.4 \%$ 으로 가장 높게 나 타났다.

2) 치과위생사의 긍정적인 인식은 '전문직 지식 과 숙련된 기술을 가지고 있다', '국민구강건강 향 상에 중요한 역할을 한다', '청결하고 단정하다'라 고 인지하는 것으로 나타났다.

3) 치과위생사의 부정적인 인식은 '치과의사와 동료 의식이 약하다', '호칭이 정립되어 있지 않다' 라고 인지하는 것으로 나타났다.

4) 연구대상자가 여성일수록 치과위생사와 간호 조무사를 구별할 수 있을수록 치과위생사의 전체 적인 인지가 긍정적으로 나타났다. 


\section{참고문헌}

1. 남용옥(2011), 치과위생학개론, 청구문화사, pp.17-22.

2. 최준선(2002), 치과 의료 서비스 향상을 위한 환자 기대도 조사 연구, 서울대학교 보건대학원 석사학 위논문, pp.45-46.

3. 이은숙(2010), 치과위생학개론, 고문사, pp.17-47.

4. http://www.mohw.go.kr

5. http://kosis.kr.

6. 신경선(2009), 치과위생사에 대한 인식 정도와 이 미지 조사, 단국대학교 행정법무대학원 석사학위 논문, pp.1-4.

7. J.M.K. Geiger, J.S. Davit(1988), Self-Image and Job Satisfaction in Varied setting, Nursing Management, Vol.19(12);50-58.

8. P. Siegel(1974), The Hygienist Inprofile, Dent Manage, Vol.14;34-46.

9. 유미선(2003), 치과위생사에 대한 인식도 및 선호 도 조사연구, 전북대학교 보건대학원 석사학위논 문, pp.1-22.

10. 강부월(2006), 치과위생사의 이미지 결정요인에 관한 연구, 한국치위생교육학회지, Vol.6(1);1-12.

11. 이보영, 이지윤, 임보미, 구효진(2011), 일부 지역 대학생들의 치과위생사에 대한 인식도 조사, 대한 치과위생학회지, Vol.13(4);277-286.

12. 최은미, 송윤신, 이선희(2004), 서울·경기지역 주 민의 치과위생사에 대한 인식도와 선호도 조사연 구, 경복대학논문집, Vol.8;399-414.

13. 김문영(1999), 간호사 이미지와 자아존중감에 관 한 연구, 경희대학교 행정대학원 석사학위논문, pp.48-52.

14. 조수희(2000), 치과위생사의 이미지에 관한 연구, 단국대학교 행정대학원 석사학위논문, pp.21-64.

15. http://www.kdha.or.kr.

16. http://www.keis.or.kr/main/www.do

17. 윤현서, 김정술, 이미옥, 김현대(2010), 일부 병원 종사자들의 치과위생사에 대한 이미지 선호 경향,
한국치위생과학회지, Vol.10(4);211-218.

18. 이병호(2011), 치과위생사의 건강증진행위와 직무 소진의 상관관계 분석, 보건의료산업학회지, Vol.5(3);111-121.

19. D. Mendez, M. Louis(1991), College student's image of nursing as a career choice, $\mathrm{J}$ of nursing education, Vol.30(7);311-319.

20. http://health.chosun.com/news/dailynews_view

21. 황미영, 이선미(2003), 치위생과 학생들의 치과위 생사 이미지에 관한 연구, 동남보건대학 논문집, Vol.21(2);117-125.

22. 한수진(1999), 치과의료기관의 치과의료서비스에 관한 환자의 만족요인 연구, 단국대학교 행정대학 원 석사학위논문, p.34.

23. 권선화(2004), 병원 의료서비스 질이 고객만족, 재이용의도에 미치는 영향에 관한 연구: 치과의료 서비스를 중심으로, 경남대학교 경영대학원 석사 학위논문, pp.65-67.

접수일자 2012년 8월 20일

심사일자 2012년 8월 29일

게재확정일자 2012년 9월 24일 